\title{
Education Challenges and Developments in Foreign Language Teaching in Croatian Law Schools Education Challenges and Development for the Future
}

\author{
Ljubica Kordić \\ University of Osijek, Faculty of Law, Croatia, Assistant Professor is at present the Head of the Department of \\ Foreign Languages at the Faculty of Law, University of Osijek, Croatia
}

\section{Doi:10.5901/jesr.2015.v5n1s1p87}

\section{Abstract}

In the modern world of global economic and political associations, the knowledge of foreign languages and communication skills represent essential factors in all professions. In this respect, knowledge of English language as lingua franca of international communication is an indispensable prerequisite for communication within the legal profession worldwide. This paper is a case-study of teaching foreign languages in Croatian Law Schools, presented on the case of the Faculty of Law, University of Osijek. In the introductory part of the paper, a short description of the status and the position of foreign language courses in the Higher Education System of the Republic of Croatia is offered. In the main part the author presents new developments in the foreign language teaching in Croatian law faculties as answers to current challenges of Croatian membership in the EU. On the example of the Faculty of Law, University of Osijek, new projects on teaching foreign languages to practicing lawyers and law students are presented, with an emphasis on the Lifelong Learning Programme for Lawyer-Linguists. This programme, as well as specific foreign language courses in Legal English, Legal German and Legal French, have been developed within the lifelong education projects for lawyers, by which young lawyers are offered an opportunity to learn and/or to improve their knowledge of the three working languages of the EU. These developments in foreign language teaching within the Croatian Higher Education System are one of the responses to current challenges of the internationalization of the modern world.

Keywords: foreign languages, international communication, lifelong learning programmes, law schools, lawyer-linguists

\section{Introduction}

The modern world is characterized by the globalization process, which is defined as the "widening, deepening and speeding up of worldwide interconnectedness" (Held, McGrew, Goldblatt and Perraton, 1999). This process has been brought about by the trends of population mobility and especially by developments in information and communication technologies, which enable establishing instantaneous links all over the world. In the new globalized world communication has taken its central facilitative role. These changes of the modern world have highlighted the importance of foreign languages and brought new requirements and challenges for foreign language teachers. With mobility being one of the main principles of the new Europe, young people need to be proficient in languages of wider communication, especially of English as lingua franca of international communication. Various EU and Council of Europe documents and reports stress the importance of learning languages and put forward multilingualism as one of the highly appreciated values of modern European society.

In the introductory part of this paper, the status of LSP in the Croatian Higher Education System will be briefly described. New developments in LSP teaching will be analysed and discussed with regard to teaching of Legal English and Legal German at the Faculty of Law, University of Osijek, Croatia. The main part will be dedicated to the Lifelong Learning Programme for Lawyer Linguists which has been developed at the Faculty of Law in Osijek as a response to current requirements of Croatian membership in the $\mathrm{EU}$ and the challenges of internationalization of the labour market.

\section{Teaching FL for Legal Purposes and intercultural Communication in the EU}

The White Book of the European Commission points out that every person should be given the opportunity to learn at least two foreign languages in addition to one's mother tongue (EU Commission, 1995). In accordance with this requirement, higher education institutions are encouraged to ensure resources and provide opportunities for students to continue learning a language appropriate to their programmes of study and fields of work (Council of Europe, 1982). Provisions of the Croatian National Curriculum Framework (NCF, 2010) determine foreign language teaching in 
Croatian secondary schools in accordance with the Common European Framework of Reference for Languages. As for higher education, the Law on Science and Higher Education as the only relevant legal regulation on higher education mentions foreign languages only within individual study programmes and general goals of the European tertiary education system. By ratifying the Bologna Declaration in May 2001, the Republic of Croatia introduced many changes in its higher education system, especially in terms of curriculum reform and student mobility as well as in teaching and learning of foreign languages. The language policies of higher education institutions should include clearly defined activities to promote foreign language learning and the acquisition of linguistic communicative skills as prerequisites for academic mobility within the European Higher Education Area. Students should master a foreign language to such a level to be able to read scientific and professional papers in a foreign language, to participate in conferences and use a foreign language in direct communication with native speakers. Due to autonomy of higher education institutions, these ideas are implemented at Croatian universities in different ways, with different intensity of FLT and different approaches to the status and importance of foreign languages (Kordić, Lj, Cigan, V. , 2013). Such a situation was confirmed by a study on teaching foreign languages at Croatian universities, which was conducted in 2009 in 143 departments of 5 Croatian universities (Osijek, Zagreb, Zadar, Rijeka and Split). The study showed that in 31\% of the departments LSP was not offered to the first year students at all, while $30 \%$ of the departments had FL in the second and third years. Only 7\% had a FL course incorporated into their curriculum continuously during 6 semesters (Poljaković, Martinović, 2009). The results of this study indicate that in Croatian faculties and other higher education institutions there are many discrepancies concerning the status of foreign languages, the intensity of FL courses, and the ECTS credits allocated to those courses. The data from the annual report of the Josip Juraj Strossmayer University of Osijek for the academic year 2010/2011 (Sveučilišni godišnjak) will be shortly presented here as an illustration of the position of FL at Croatian faculties. The language of law being in the focus of the paper, the data presented here specifically refer to foreign languages for specific purposes.

\section{FLT in Croatian Tertiary Education}

The University of Osijek encompasses nine faculties, one Academy of Arts and five departments: Department of Mathematics, Department of Physics, Department of Biology, Department of Chemistry, and Department of Cultural Studies. Foreign languages taught as LSP at the University are English and German, as well as Italian, which is taught as the third FL at the Academy of Arts.

There are many differences between the faculties in the status, number of credits allocated to the course and even the number of teaching hours of foreign language courses per semester. The Department of Chemistry offers LSP only in the first two semesters, and the Departments of Physics and Mathematics, as well as that of Cultural Studies, have LSP in the first four semesters. The Department of Biology does not have any foreign languages in its curriculum at all. At the Faculty of Agriculture, LSP is taught only to the first year students, but more intensely than at other faculties. That workload is allocated 6 ECTS per semester, which is the highest credit allocated to LSP within the Osijek University. At the Faculty of Food Technology, LSP is learned only by the first year students as a compulsory course in all study groups, with the exception of the "main" study programme Food Technology, in which LSP is taught for four semesters at the BA level. The course is allocated 2 credits in every semester. At the Faculty of Law, FL for Legal Purposes is taught in the first four semesters as a compulsory course, with double the intensity in comparison to other faculties. It is also offered as an elective course in the ninth semester. Nevertheless, the credits allocated represent an average at the University level: 3 ECTS for compulsory courses and 4. 5 for the elective courses English for EU Law and Deutsch für Strafrecht (Kordić, 2013). The cases presented here indicate a strong influence of the University autonomy, reflected in differences in status, intensity of teaching and the number of credits allocated to foreign language courses. A slight improvement of the situation can be noticed in recent years, but the annual report for the academic year 2010/11 clearly implies that in spite of the declaratory appreciation of multilingualism in the EU, this appreciation remains largely invisible in the teaching practice, since foreign languages are not incorporated in the curricula of two out of nine faculties, while in one faculty no ECTS credits are allocated to FL courses.

\section{Developments in LSP Teaching in the Faculty of Law in Osijek}

Emergence of different varieties of LSP and the developments in this field in terms of methodology and teaching materials have been the topic of many discussions and scientific papers. The reasons for this boom in the linguistic theory of LSP and its practical application in FL teaching in secondary and higher education all over the world can be 
seen in the demands of the New World after World War II, a revolution in linguistics and a shift of the focus from the teacher to the learner (Hutchinson and Waters, 1987: 5). By putting the learner in the centre of the teaching discourse, learner's needs became as important in FL teaching as the teaching methodology. For the first time, the teaching content, the design of teaching materials and the choice of teaching methods were based on the learner's reason for learning (Hutchinson and Waters, 1987: 19). This new movement in teaching approach is known as the learner-centred approach. This approach implies various developments in the teaching practice in terms of teaching materials developed in accordance with learner's needs (based on needs analysis), teaching is perceived as guiding, scaffolding and facilitating learning rather than transmitting linguistic knowledge to the learner, real-life tasks get priority in teaching, learners are included in the teaching process with more autonomy and responsibility, they accept more challenging tasks and fulfil them autonomously by using modern technologies.

The changed approach and changes of social, environmental and technological circumstances have reflected in a specific way on the most recent developments in teaching foreign languages for specific purposes at the tertiary level. These developments, well elaborated by Elžbieta Jendrych, include: a) content-and-language-integrated-learning (CLIL), b) use of didactic case-studies, c) corpus studies conducted for teaching purposes and aimed at identifying high frequency language elements: terms, specialized lexis items, collocations, phrases, formulae, acronyms, etc. that need to be prioritized in language courses, d) more effective course-books with higher terminology indexes, e) extended use of online materials, f) teaching writing for specific purposes and g) teaching professional culture and non-linguistic skills (Jendrych, 2013: 46). This list of the current developments in LSP illustrates all the complexity of teaching foreign languages for specific purposes at the higher education level and indicates how many challenges and new requirements modern LSP teachers are confronted with. In the following paragraphs the situation in teaching foreign languages for legal purposes at the University of Osijek shall be presented in the light of these new requirements in teaching LSP at the tertiary level.

a) Content-and-language-integrated-learning (CLIL)

The concept of CLIL - Content and Language Integrated Learning - has been strongly advocated by the Language Division of the Council of Europe (2004) on all education levels, especially on the university level. According to main principles of the CLIL-approach, in most European universities foreign languages for specific purposes are instructed by teachers who teach both subject matter and the foreign language. Although English and German as foreign languages for specific purposes are taught in most Croatian universities, the dominant FL is English. This phenomenon is especially observable in recent years, when student mobility between European universities has been intensified. Consequently, not only LSP courses, but also some subject matter courses are held in English. Thus it can be stated that English has become not only the lingua franca of professional and business communication, but also of education and academic communication worldwide. No wonder that this new situation is often informally determined as "Englishization" of tertiary education. These new circumstances demand a new kind of FL teacher, too - either a teacher who has learned a subject matter to such an extent that he/she can competently teach students the content and language integrated topics, or a content matter teacher with good linguistic competence. In my contacts with LSP teachers from other European countries, the latter solution is often encountered in some European countries like Poland, Germany or the Czech Republic. Teaching Legal English by lawyers who additionally have studied English as a foreign language or have studied law (even for several semesters) in the USA or Great Britain is not a rare situation at European law schools. But the prevailing case - like in the Republic of Croatia - is that graduated FL teachers teach subject matter topics in the respective FL. Teaching subject matter in a foreign language is a very demanding task, and FL teachers usually learn the subject matter by individual additional learning from legal textbooks or undertake postgraduate or doctoral studies within the subject matter sciences or those related to them (e. g. FL teachers instructing Business English or Legal English can enrol in European Doctoral Studies at the University of Osijek, which is an interdisciplinary study programme integrating law, political studies and economics).

Teachers teaching FL for Legal Purposes at the Faculty of Law, University of Osijek, are able to fulfil this requirement due to the opportunity to participate several years ago in the TEMPUS project "Foreign Languages in the Field of Law - FLIFL", coordinated by the Faculty of Law from the University of Zagreb. Target groups of the project were graduated lawyers and FL teachers in the field of law. The main goals of the project were defined as 1) education of FL teachers employed at Croatian law faculties in order to improve their professional credibility in LSP ("Teacher Training Programmes"), 2) education of lawyers in foreign languages ("Lawyer Training Programmes") and 3) development of FL curricula and modern teaching methodology in conformity with the Bologna requirements and following the needs of Croatian law students (needs analysis was conducted among Croatian lawyers at the beginning of the Project). Teacher training within the Project was organized as a series of workshops including the following topics: Basics of the EU Law, 
European Private Law, European Comparative Law, Introduction to the Analysis of EU Law, Introduction to FL for Legal Purposes; Legal Translation and Terminology, Communication Skills for Lawyers, Introduction to Forensic Linguistics, Intercultural Communication for Lawyers, Legal and Linguistic Aspects of Multilingualism, Teaching Legal English - Skills and Materials, and, finally, Language Policy of the EU: Sources of Information. Workshops were organized and delivered by estimated professors teaching at European universities, like Peter Sandrini of the University of Innsbruck, Paul Verluyten, Diane Phillips, and Ludger Kremer of the University of Antwerp, Werner Schroeder, Andreas Müller, and Eva Lechner (University of Innsbruck), John Olsson of the Forensic Linguistics Institute, Powys Wales UK, Helmut Heiss, Sture P. Ureland, and Olga Voronkova of the University of Mannheim, etc. ${ }^{1}$ The knowledge and skills acquired in these workshops made Croatian LSP teachers more competent to teach legal content in their foreign language courses and capable of developing new education programmes which could respond to new professional circumstances and challenges of political, economic and legal changes in Europe.

b) Use of didactic case studies

The second characteristic of recent developments in LSP teaching refers to the introduction of specific cases analysed and solved for didactic purposes. In the field of law, this refers to solving simple legal cases: our second year students are asked to solve a specific case of tort law concerning the missing dog. In this way they are involved in solving a real-life task by following the methods used by lawyers in their professional life. Individual work on relevant legal provisions, prepared at home, is combined with classroom group work in simulations of the court case. By introducing concrete case-study methods in FL courses at law faculties, the requirement for real-life tasks as one of the recent developments in LSP teaching is fulfilled. From a didactical point of view, the case-study method is very fruitful because foreign language is used to solve a real-life task, thereby developing productive writing and speaking skills. The case-study method is student-centred and the language is used in a natural way: as a means, not as an end of teaching discourse activity (Jendrych, 2013: 48).

c) Corpus studies conducted for teaching purposes and aimed at identifying high frequency language elements

This requirement can be fulfilled by those FL teachers who are interested in academic writing and linguistic research. This especially refers to research in legal terminology, collocations and phrases which frequently occur in the language of law and thus represent a linguistic feature which should find its place in teaching specific legal language. At the Faculty of Law in Osijek, this requirement is completely met, because all the three FL teachers explore Legal English and Legal German and apply the results of their research in designing their FL courses. As teaching Legal English and Legal German as compulsory courses is partly restricted by the subject matter content of the respective course books and by the limited number of teaching hours per semester, the results of those linguistic studies have been applied to the greatest extent in the development and design of the Lifelong Learning Programme for Lawyer Linguists, which shall be presented in the main part of this paper.

d) More effective course-books with higher terminology indexes

This requirement is partly fulfilled. Although there are modern textbooks of Legal English and Legal German designed in conformity with recent developments within the CLIL-approach, the LSP teachers of the Osijek Faculty of Law are currently working out the idea of developing a new, more effective course-book, which would be based on the needs analysis. It is important to stress that the foundation for this has been built by an extensive and detailed needs analysis among law students, graduated lawyers and law practitioners in different fields of legal profession, which was conducted in 2003 (Kordić, Mujić, 2004) and again in 2014 (Kordić, Papa, 2014).

e) Extended use of online materials

Modern computer technologies and achievements of information sciences have been applied in the teaching process at Croatian faculties. This especially refers to students preparing Power Point presentations on legal topics, for which they can use both published legal sources and internet sources. Online sources are also used by students in solving their case study tasks. Still, apart from using sources published on the internet and online dictionaries, there are many other possibilities for law students to use computer technology and online materials, like creating students' own website with the list of legal terminology. This idea has been successfully carried out in some European universities, like in the Foreign Language Centre of the University of Wrocław². Apart from that, there are also online LSP courses that can be used by students on their own. At this point it has to be stressed that students must be warned to use internet information selectively and carefully and to pay attention to credibility of some internet sources they frequently use, e. $\mathrm{g}$. Wikipedia.

${ }^{1}$ Retrieved from: www.pravo.unizg.hr/_...Tempus_workshops_final_27_March.doc, accessed 28/02/ 2015, 19:08

2 From the workshop "Writing in Plain English" held by Aleksandra Łuczak in "The first Legal English Workshop SHARE \& GAIN", Suprasl, Poland, 18-19 September 2014 
f) Teaching professional culture and non-linguistic skills

This requirement is partly fulfilled by means of legal texts dealing with specific topics of the national law (in our case Croatian) and the law of countries where the foreign language is spoken (German law system, British and American legal system). In legal language courses, LSP teachers develop students' cultural and non-linguistic skills as well by sharing their experiences and pointing out the similarities and differences between two professional cultures. Another method we use to achieve this goal is giving individual tasks to students, for example, to watch a TV-series or a movie on specific legal topics and discuss the differences in the classroom.

g) Teaching writing for specific purposes

The achievements within this requirement are rather poor at Croatian law faculties. The emphasis on oral communication skills and the low intensity of teaching hours per week have led to neglecting the importance of writing skills in Croatian law faculties, including the Faculty of Law in Osijek. The only type of written exercise done within FL courses refers to summary writing combined with reading comprehension and determining subtitles to specific legal texts. Our experience and contacts with fellow teachers from other European universities give evidence of far more advanced and intensive use of writing skills, especially in Legal English courses. An interesting example represents creating a website with legal glossary developed by law students, writing legal provisions in plain English, drafting official letters or even contracts in Legal English (Luczak, 2014). It has to be mentioned here that our needs analysis several years ago (2003) showed great interest of our students in speaking skills in LSP, so during the years we have tried to meet this requirement and combine it with internalisation of as much as possible legal terminology and phraseology. Taking into account low intensity of FLT courses per semester and focusing on developing oral communication competence in the respective foreign language, there was little time left to be dedicated to writing skills. Keeping all the factors mentioned here in mind, in my opinion it makes more sense to develop writing skills within groups of students with advanced FL knowledge, like students and graduated lawyers who enrol in lifelong learning programmes in foreign languages and who aspire towards careers on the wider EU labour market. This is the case with the current Lifelong Learning Programme for Lawyer Linguists, which will be described in the following part of this paper.

\subsection{Lifelong Learning Programme for Lawyer Linguists at the Faculty of Law in Osijek}

Political and economic changes in modern Europe have reflected on the teaching approach in LSP in a specific way. Financial deregulation, political and economic integrations, greater job mobility and intensified international cooperation, along with the expansion of new communication technologies facilitated and speeded up the international communication and highlighted the importance of foreign languages and communication skills. All these changes have strongly influenced learner's needs in the FL teaching process, especially in the field of FL for legal purposes, which is in the focus of interest in this paper.

Following the guidelines of the Strategy of the Josip Juraj Strossmayer University of Osijek 2011-2020 (Strategy, 2011: 54), the Department of Foreign Languages of the Faculty of Law initiated the introduction of a new lifelong education programme for lawyers. It was a pragmatic response to political and economic changes and requirements of the EU labour market which became accessible to Croatian lawyers as well. The European Personnel Selection Office (EPSO) of the European Commission announced job opportunities on the European labour market with the prospect of Croatian full membership in the EU in July 2013. According to the data of December 2012, the European Union needed translators, interpreters, lawyer linguists, administrators, heads of departments and other officials in the field of Communication, Legal Affairs and Programme Management in the offices of the European Commission, the Court of Justice of the EU and other institutions whose employees should master both legal and linguistic knowledge ${ }^{3}$. As a response to new job opportunities for Croatian lawyers, Departments for Foreign Languages of the Faculty of Law in Zagreb and in Osijek initiated their Lifelong Education Programmes for Lawyer Linguists: the former in the summer semester of the year 2011/12 and the latter in the winter semester 2012/13. The Lifelong Learning Programme for Lawyer Linguists in Osijek was organized on similar principles as the Programme of the Zagreb Faculty of Law, but in conformity with specific circumstances at the respective faculty, especially in terms of FL competences and special professional interests of its teaching staff. The Programme developed in Osijek was approved and officially accredited by the Senate of the Osijek University. Altogether 22 ECTS credits were allocated to the Programme, the maximum credit number that can be achieved by individual participant being 18. It encompasses seven courses with altogether 170 teaching hours. The Programme was offered in the winter semester of 2012/2013 to graduate lawyers and 5th year law

${ }^{3}$ Retrieved from: $h t t p: / /$ www.europa.eu/epso/apply/jobs/temp/index_en.htm , accessed 06/09/2012, $20: 32$ 
students and was financed by a participant fee payable in instalments. The Programme was initially introduced to meet demands of the EU institutions for skilled legal translators, but today the target group comprises young lawyers with good foreign language skills who are interested in finding jobs in different EU institutions and/or international companies, due to diverse job opportunities offered to Croatian lawyers on the EU market. The programme is mostly carried out by FL teachers teaching at the Faculty of Law in Osijek, but also by guest professors from the Faculty of Humanities (for the courses Croatian Language for Lawyer Linguists and Introduction to French Legal Translation). Lectures and exercises within the Programme were held on Fridays and Saturdays during the period of 10 weeks. In the first term (the year 2012/2013), 25 participants were included in this Programme, in the second 18 participants. In this academic year (2014/2015) we have enrolled 10 participants. The reduced number of participants can be seen as a result of the economic crisis and the fact that most of them are unemployed.

The programme carried out in Osijek includes the following courses:

1) Introduction to the Theory of Legal Translation and Terminology

2) Croatian Language for Lawyer Linguists

3) Introduction to the EU Law

4) Introduction to French Legal Translation

5) EU Vocabulary and Online Language Tools

6) Exercises in Legal Translation - English Language

7) Exercises in Legal Translation - German Language.

Table 1: Lifelong Learning Programme for Lawyer Linguists at the Faculty of Law in Osijek

\begin{tabular}{|c|c|c|c|c|}
\hline Course & Teaching & Status of the course & ECTS| & Type of assessme \\
\hline Compulsory courses & hours & stalus or the course & ECIS & lype ol dasessme \\
\hline Introduction to the Theory of Legal Translation and Terminology & 15 & Compulsory & 3 & Oral exam \\
\hline Croatian Language for Lawyer Linguists & 20 & Compulsory & 3 & Written exam \\
\hline Introduction to the EU Law & 15 & Compulsory & 3 & Oral exam \\
\hline Introduction to French Legal Translation & 20 & Compulsory & 3 & $\begin{array}{l}\text { Written exam } \\
\text { (translation) }\end{array}$ \\
\hline EU Vocabulary and Online Language Tools & 10 & Compulsory & 2 & Written exam \\
\hline Legal English-Module & $\begin{array}{c}\text { Teaching } \\
\text { hours }\end{array}$ & Status & ECTS & Type of Assessment \\
\hline Exercises in Legal Translation - English Language FL 1 & 20 & Elective & 2 & $\begin{array}{l}\text { Written exam } \\
\text { (translation) }\end{array}$ \\
\hline Exercises in Legal Translation - German Language FL 2 & 20 & Elective & 2 & $\begin{array}{l}\text { Written exam } \\
\text { (translation) }\end{array}$ \\
\hline Legal German Module & $\begin{array}{c}\text { Teaching } \\
\text { hours }\end{array}$ & Status & ECTS & Type of Assessment \\
\hline Exercises in Legal Translation - German Language FL 1 & 20 & Elective & 2 & $\begin{array}{l}\text { Written exam } \\
\text { (translation) }\end{array}$ \\
\hline Exercises in Legal Translation - English Language FL 2 & 20 & Elective & 2 & $\begin{array}{l}\text { Written exam } \\
\text { (translation) }\end{array}$ \\
\hline
\end{tabular}

With the exception of the courses in EU Law and EU Vocabulary and Online Language Tools, the courses are mainly focused on language. In accordance with recent developments in FL teaching, the Programme follows the CLIL approach, as the learner, his interests and learning goals are the central criterion for syllabus design, for choice of teaching materials and most appropriate teaching methods.

All participants have been trained in legal translation in three languages: English, German and French. The knowledge of these three working languages of the EU is required in most jobs announced on the website of the European Personnel Selection Office. ${ }^{4}$ As most participants do not speak French, Introduction to French Legal Translation is an obligatory course focused on teaching general communication in French including some basic legal terminology.

As for English and German, participants are separated in two groups in these classes: one group includes those who have learned English as their FL 1 and German as their FL 2, and the second group those with German as FL 1 and

${ }^{4}$ Retrieved from http://europa.eu/epso/apply/jobs/temp/index_en.htm\#chapter2, accessed 28/02/2015, 23:03 
English as FL 2. Exercises in translation of legal texts in English and in German are focused on the translation process and possible ways of approaching the translation. Teaching materials in both languages are chosen from EU legislation of different types, while several texts pertain to the Croatian national law. Within these courses some changes have been introduced in line with the demands and wishes of our participants: in the beginnings of the Programme, exercises were focused on the analysis and discussion of translations they have done as their homework between sessions, as well as of the translation process, the specific approach to translation of legal texts, specific features of the lexis (polysemy!), syntax, frequent grammar structures and collocations typical of the respective legal language. As learners' needs have been our basic criterion in designing the Programme from the beginning, we have introduced slight changes in the Programme at the request of our participants or based on our own experiences from previous years. This year, therefore, based on experiences of our former attendants who applied for positions in EU institutions or international companies, we have introduced trainings in oral interviews in the last four hours of these courses, because oral interviews conducted by the employer represent an integral part of employment procedure in Europe. Accordingly, from this year on, participants are informed in the first session within the Programme about the employment procedure in EU institutions by a FL teacher who experienced all the stages of job application procedure carried out by the EPSO.

Within the course Croatian Language for Lawyer Linguists participants are trained in good writing skills, in appropriate use of Croatian orthography and punctuation, with specific reference to dilemmas emerging while writing translation in standard Croatian language. In this course, students participate in the course design by pointing out their own problems arising in writing texts in Croatian language.

Introduction to the EU Law has been incorporated in the Programme primarily to meet the needs of those graduate lawyers participating in the Programme who did not have this course in their curriculum while studying law. The participants who had passed the exam in EU Law in their regular study time are exempted from attending this course.

EU Vocabulary \& Online Language Tools has been introduced as a response to demands of modern business communication as well as to recent developments in translation methodology and translation tools designed by using information technologies. The course is taught by an experienced EFL teacher who was trained in these skills within the TEMPUS project mentioned in the introductory part of this paper. This teacher is probably the most proficient user of information technologies and online translation tools among the teaching staff at the Faculty of Law in Osijek.

\subsection{Designing the Course Introduction to the Theory of Legal Translation and Terminology: Achievements and Perspectives}

As mentioned in the introduction to this paper, the entire Programme of education of lawyer-linguists was designed according to learners' needs (learner-centred), based on the CLIL-approach and adjusted to specific circumstances of the Osijek University, especially in terms of appropriate teaching staff equipped and competent to teach specific subjects. Thus, Introduction to the Theory of Legal Translation and Terminology was designed and delivered by the author of this paper. The principal factors taken into consideration in the process of the course design were the purpose of the course and the target group of learners, who were equipped with little or no theoretical linguistic knowledge in legal language and in translation process in this field. As one of the main prerequisites for successful teaching outcomes is a competent and motivated teacher, able to motivate his/her students and meet their needs in the respective teaching process, the syllabus was designed based on scientific research the teacher (author of this paper) has conducted in the fields of German, English and Croatian Legal Language since 2004, as well as on written sources on legal translation, specifically Baker's Encyclopedia of Translation (Baker, 2009), New Approach to Legal Translation by Susan Šarčević (Šarčević, 1997), and Prunc's Entwicklungslinien der Translationswissenschaft: Von den Asymmetrien der Sprachen zu den Asymmetrien der Macht (Prunc, 2012).

Apart from the introductory lecture, the course comprises seven basic topics delivered in two hours per week during 10 weeks. Those topics are: 1) General features of legal language; 2) Linguistic features of the German, English and Croatian language of law, 3) Translation as a communication process, 4) Basics of the translation approach in the field of law, 5) EU terminology and phraseology, 6) Poetic elements in legal language - a comparative approach, 7) Summary of the course - most important issues. In the first lecture some universal features typical of the language of law are presented and discussed, such as: a) polysemy and complexity of legal terms, b) difficulties in understanding legal texts due to frequency of Latin loanwords and abstract terms, c) nominal style and frequency of complex and complicated sentences, and d) numerous text types of specific rigid structure and form. In the second lecture linguistic features of German, English and Croatian legal language are discussed on all levels of linguistic analysis apart from phonetics: lexis and semantics, morphology and syntax, word formation and style. Every feature is illustrated by examples in three 
languages and every session is concluded by a specific task for participants. In the third lecture the translation process is observed from the perspective of communication theory and different translation theories and approaches are discussed with specific reference to legal discourse. The forth lecture is dedicated to modern approach to the translation process, by highlighting the principle defined by Professor Erich Prunc of the University of Graz as "Enttrohnung des Ausgangstextes" and by explaining recent developments of the modern functionalist approach as defined by Vermeer (in: Baker, 2009). The purpose of translation, the target language and the final user of translation as main factors of recent developments in translation theory are discussed and illustrated with specific translation tasks. Special attention is paid to the specific approach required in legal translation, which has been informally determined as "from-the-macro-level-to-themicro-level-approach". In the conclusion of the topic, participants are warned about several problematic issues in legal translation which should be kept in mind in the process of translation, especially concerning conceptual and cultural differences between specific legal systems. In the lecture dedicated to EU terminology students are informed about the importance of the standardization of the EU terminology and consistency in using standardized terms. Additionally, the list of most common EU terms in the field of EU legislation and EU institutions in the three languages is offered to participants, as well as the list of some new EU terms that are not used or are used in a different meaning in standard British English. The lecture dedicated to poetic elements in the language of law discusses this unusual phenomenon from the historic perspective, pointing out that back in 1815 Jakob Grimm had published an article titled "On the Poetry of the Legal Language" (Kordić, 2010). In the main part of the lecture, by using a comparative approach, specific examples of metaphor, alliteration, tautology, personification and doublets are presented in German, English and Croatian language of law, based on the comparative corpus research in German, Croatian and English criminal laws that the author of this paper carried out in 2009 (Kordić, 2010). The final session is planned as a summary of most important facts on legal translation and preparation for the oral exam.

\section{Concluding Remarks}

In the introductory part of the paper recent developments in LSP teaching as applied in the Faculty of Law in Osijek have been discussed: a) content-and-language-integrated-learning (CLIL), b) use of didactic case studies, c) corpus studies conducted for teaching purposes and aimed at identifying high frequency language elements, d) more effective course books with higher terminology indexes, e) extended use of online materials, f) teaching writing for specific purposes, and g) teaching professional culture and non-linguistic skills. A short presentation of the Lifelong Education Programme for Lawyer Linguists conducted successfully for three years at the Faculty of Law, University of Osijek, Croatia, can well illustrate that best fulfilment of those requirements can be expected in such LSP programmes developed for specific groups of highly motivated learners attending the courses with clearly defined real-life purposes. It can be concluded that new developments in LSP teaching, resulting from political and economic integrations, greater job mobility and intensified international cooperation by means of new communication technologies, find their most appropriate application in the lifelong learning programmes designed in accordance with real life needs and aspirations of the target group of learners. The learner-centred approach opens the opportunity to students to participate in the course design and to help adjust it to their needs and current requirements of the labour market. However, this implies new requirements, challenges and responsibilities for LSP teachers.

\section{References}

Baker, M. \& Saldanha, G. (Eds. ). (2009). Routledge Encyclopedia of Translation Studies, Abingdon: Routledge.

Barišić, Zdenka (ed), (2011): Sveučilišni godišnjak Sveučilišta J. J. Strossmayera u Osijeku 2010/2011 [Annual of the J. J. Strossmayer University of Osijek 2010/2011]. Osijek: Sveučilište J. J. Strossmayera.

Held, D, McGrew, A, Goldblatt, D, Perraton, J. (1999): Global Transformations. Stanford: Stanford University Press.

Hutchinson, T. , Waters, A. (1987): English for Specific Purposes: A learning-centred approach. Cambridge: Cambridge University Press.

Jendrych, Elžbieta: Developments in ESP. Studies in Logic, Grammar and Rhetoric, 34 (47) / 2013, pp. 43-59.

Kordić, Lj, Mujić, N. (2004): Strani jezik u funkciji pravne struke: istraživanje stavova djelatnih pravnika i studenata prava [Foreign Language for Legal Purposes: Exploring Attitudes of Practicing Lawyers and Law Students] . Pravni vjesnik Pravnog fakulteta Sveučilišta Josipa Jurja Strossmayera u Osijeku, 3-4/2003, pp. 57-77.

Kordić, Lj. (2010): Elementi neformalnosti i poetičnosti u jeziku prava. Zbornik radova HDPL: Prostor i vrijeme u jeziku - jezik u prostoru i vremenu. Međunarodna konferencija HDPL, Osijek, svibanj 2009 (175-1859. [Informal and Poetic Elements in the Language of Law. Proceedings of the International CAAL Conference 'Space and Time in Language - Language in Space and Time', Osijek, May 2009 (175-185)]. Zagreb-Osijek: HDPL \& Filozofski fakultet Sveučilišta J. J. Strossmayera. 
Kordić, Lj. , Cigan, V. (2013): Teaching and Learning of Foreign Languages for Legal Purposes in Croatia. Studies in Logic, Grammar and Rhetoric, 34 (47) / 2013, pp. 59-75.

Kordić, Lj. , Papa, D. (2014): Suradnja među katedrama u svrhu podizanja kvalitete nastave stranih jezika struke - komparativni pristup [Cooperation between Faculty Departments to the Purpose of Quality Improvement in Teaching FL for Specific Purposes - a Comparative Approach]. Pravni vjesnik Pravnog fakulteta Sveučilišta Josipa Jurja Strossmayera u Osijeku, 1/ 2014, pp. 73-88.

Luczak, A. (2014): Writing in Plain English (workshop). The 1'st Legal English Workshop SHARE \& GAIN, Suprasl, Poland, 18-19 September 2014

Poljaković, I. , Martinović, A. (2009): A New Approach to Teaching Foreign Languages in Universities. In: Granić, J. (ed. ): Language Policy and Language Reality, pp. 225-236. Zagreb: HDPL.

Prunc, E. (2012): Entwicklungslinien der Translationswissenschaft: Von den Asymmetrien der Sprachen zu den Asymmetrien der Macht. Frank \& Timme. Šarcević, S. (1997): New Approach to Legal Translation. The Hague-London-Boston: Kluwer Law International.

\section{Documents}

Common European Framework of Reference for Languages - CEFR (2005) [ (2005) Zajednički europski referentni okvir za jezikeZEROJ]. Zagreb: Školska knjiga.

Council of Europe (1982): Recommendation No. R (98)6-Appendix to Recommendation No R (82) 18

Josip Juraj Strossmayer University of Osijek (2011): Strategy of the Josip Juraj Strossmayer University of Osijek 2011-2020. Osijek: Josip Juraj Strossmayer University.

\section{Internet Sources}

Croatian National Education Standard [Hrvatski nacionalni obrazovni standard - HNOS]. Ministarstvo znanosti, obrazovanja i športa (2005)] http: //public. mzos. hr/Default. aspx?sec=2199 [Access: 18/10/2010]

European Commission (1995). Weißbuch zur allgemeinen und beruflichen Bildung - Lehren und Lernen - Auf dem Weg zur kognitiven Gesellschaft. http: /leuropa. eu/documentation/official-docs/white-papers/index_de. htm [Access10/04/2013]

National Curriculum Framework [Nacionalni okvirni kurikulum za predškolski odgoj i obrazovanje te opće obvezno i srednjoškolsko obrazovanje - NOK] (2010), http: //public. mzos. hr/Default. aspx?sec=2685_[Access: 18/10/2011]

Science and Higher Education Act [Zakon o znanstvenoj djelatnosti i visokom obrazovanju]. Official Gazette, 123/03 (2003) http: I/narodne-novine. nn. hr/clanci/sluzbeni/306330. html [Access: 18. 10. 2011]

www. pravo. unizg. hrl_.../Tempus_workshops_final_27_March. doc [Access: 28/2/2015, 19: 08]

www. europa. eu/epso/apply/jobs/temp/index_en. htm [Access 06/09/2012, 20: 32]

www//europa. eu/epso/apply/jobs/temp/index_en. htm\#chapter2 [Access: 28/2/2015, 23: 03] 
